\title{
Limits of devolution: localism, economics and post-democracy ${ }^{1}$
}

John Tomaney

\section{Abstract}

This paper challenges the narrowly founded but untroubled consensus about the alleged benefits of the Conservative government's devolution programme. It suggests that too much attention has been paid to purported benefits and too little regard to the potential risks. It draws attention to international evidence that suggests that the distribution of the benefits of devolution is crucially dependent on its design. It critically examines the case for the currently offered model of devolution and finds the underpinning economic model and limited forms of democratic accountability are likely to produce regressive social outcomes and the reinforcement of existing local elites. It calls for a wider public debate and a fuller democratic scrutiny of the model of devolution on offer.

Keywords: Devolution, elected mayor, Northern Powerhouse, democratic accountability, decentralisation, regionalism.

Contact Details: Professor John Tomaney, Bartlett School of Planning, UCL Faculty of the Built Environment, Central House, 14 Upper Woburn Place, London, WC1H ONN; email: j.tomaney@ucl.ac.uk

\section{Introduction}

We live on the cusp of an age of localism and decentralisation that will bring benefits in terms of improved economic development and enhanced democratic accountability. This, at least, is the new ruling orthodoxy. A recent and broadly representative expression of the conventional wisdom was offered by Grant Thornton/Localis, which added to the 
proliferation of think tank reports outlining the purported advantages of the Conservative government's 'devolution' programme. According to this analysis, the benefits of 'devolution' are fivefold. First, fiscal devolution will aid rebalancing because this will create 'self-reliant cities' which prove to be 'more resilient'. Second, local government is more efficient than central government, as demonstrated by its ability to absorb public expenditure cuts. Third, devolution offers a way of invigorating local democracy. To wit, 'with more power vesting at the local level and the associated local media coverage, there should follow greater democratic engagement'. Fourth, devolved government will mean that SMES will be able 'to plug into the public service supply chain'. Finally, decentralisation will allow innovative approaches to place-based and outcome-focused services. ${ }^{2}$

There is no denying that England is a highly centralised jurisdiction and there is a strong case for devolution. But this does not preclude the case for careful scrutiny of the claims on which the government's case for its programme rests. In several ways, the report by Grant Thornton/Localis encapsulates the weaknesses in the way in which the debate about decentralisation in England is currently framed. Firstly, the focus on the benefits precludes consideration of the potential costs of devolution, which might be expected to arise as a result of large scale political and administrative change. Secondly, the claims outlined above are largely unsupported by evidence. Indeed, each of these claims can be challenged. For instance, self-reliance can be source of weakness for cities as well as strength; the relationship between devolution and democratic renewal is highly uncertain, especially in a context where local media are weak and declining; public procurement rules will remain a matter of national and European legislation in ways that are likely to limit the scope of local action. The forms of 
devolution proposed in England are highly constrained and limited. More generally, the debate about the government's devolution plans is occluded by an absence of historical and comparative perspective. For instance, press coverage in North East England was breathless with the possibility of a "historic devolution deal" which would gift the region a $f 30 \mathrm{~m}$ per annum infrastructure fund and the possibility of additional levy, subject to an elected Mayor being imposed on the region. Yet, these resources compare poorly to the $f 222 \mathrm{~m}$ per annum allocated in 2007 Comprehensive Spending Review to One North East (the development agency established by the previous Labour government and subsequently abolished by the Coalition). This paper challenges the narrowly founded but untroubled consensus about the benefits of the government's devolution programme.

\section{A Global Trend?}

Decentralisation of government and governance is an international phenomenon that is seen to meet multiple objectives of increasing the efficiency of public services, improving legitimacy and accountability of political institutions, fostering the growth of local and regional economies and incubating policy innovation - creating 'laboratories of democracy' in the words of the US Supreme Court Judge, Louis Brandeis. Internationally, we can identify a widespread, if highly heterogeneous, trend toward decentralisation by national governments. Differences in approaches to decentralisation are conditioned by broader processes of globalisation, the growing complexity of the state and growing demands upon it and the variety of motivations and national contexts (historical, political, economic, cultural) in which it has been introduced. The assertion of territorial identities was a key rationale in early shifts toward more decentralised state structures, but latterly economic arguments 
have dominated as governments seek an 'economic dividend' from decentralisation in terms of efficiency gains and improved economic growth.

In the UK, these arguments appear to carry greater weight in a context of weak national recovery from a severe recession, enduring public and private indebtedness and deep and lasting austerity. Governments and international organisations such as the World Bank, Organisation of Economic Cooperation and Development (OECD) and European Union (EU), expect decentralisation to deliver more efficient local services and provide greater stimulus to local economic growth. The recent government policy agenda in England constitutes a particular version of these broader processes and rationales in focusing, at various times, upon the relationship between decentralisation, localism and the 'Big Society'. The current case made for devolution in England similarly rests on claims made about its anticipated contribution to improved efficiency in the delivery of public services and the promotion of local economic growth as part of efforts to 'rebalance' the UK economy. But as I will argue below, there is something distinctively regressive about the Conservative approach in England which is likely to frustrate its avowed aims, although it may yet serve the strategies of the Conservative party and some Labour local government interests.

The international literature on decentralisation is focused upon the redistribution of power and resources to lower tiers of government. The literature produces ambiguous and, at times, contradictory findings about the impacts of decentralisation on governance, public services, local economic growth and wellbeing. These are partly the result of data and methodological limitations and a product of the questions that are asked. For example, we find quite 
contradictory evidence about the impacts of decentralisation on the efficiency of local services, reflecting the difficulties in finding adequate means of measurement and data and depending upon the specific policy areas addressed: some studies report improvements in outputs and others report deteriorations across different sectors such as health, education, and transport ${ }^{3}$.

In addition, the literature on decentralisation tends, with one or two exceptions, does not draw strong distinctions between the efficacies of different tiers of sub-national government covering a variety of spatial scales, tending instead to explore the principles of decentralisation itself. As an international phenomenon decentralisation has adopted many forms and been enacted at different spatial scales. Thus, much of the international literature is concerned with decentralisation to the regional instead of - or as well as - the local scale and terms such as regionalisation, decentralisation and devolution are often used interchangeably and/or inconsistently. A systematic review of existing studies reveals the challenges of analysing decentralisation processes at the local scale and casts doubt on many of the claims that are being made in the English debate.

Rather than simply heralding the advantages of localism, it is more sensible to attempt an assessment of the strengths, weaknesses, opportunities and threats associated with devolution both in principle and in practice in England. For instance, one of the perceived and on the face of it convincing - advantages of devolution is that it allows more 'joined-up' or better coordinated public policies, overcoming problems of delivering separate public policies through central government departments and agencies (the policy 'silo' problem) by 
having a clear territorial focus for policy. But, 'joining up' policy can give rise threats as well as opportunities. For instance, Sir Hugh Taylor, former permanent secretary at the Department of Health, has highlighted some perceived drawbacks of regional decisionmaking in a context of austerity:

'I'm nervous that we'll be trading road maintenance services for health as cash limits bite. My worry is that mixing up budgets will lead to reductionism not improvement. Devolution mustn't displace the big issues facing health where we are still trying to run the cheapest system in the developed world and making savings' ${ }^{4}$

The issues at stake here are not merely technocratic ones but have an inherently political character. Devolution in a context of austerity raises the probability of invidious decisions about cuts being the order of the day rather than efficiency gains through better joining-up.

\section{Financing devolution}

The claim that devolution will give rise to an 'economic dividend' figures strongly as a trope in the current debate. But the evidence suggests that the nature of any dividend is contingent upon the context in which it is introduced. The key issue at stake is the degree to which devolved systems are accompanied by fiscal mechanisms of territorial redistribution. George Osborne's announcement in October 2015 that full control of business rates would be devolved to local councils, along with the power to reduce (but not raise) them, was welcomed by the Taxpayer's Alliance which argues that it would lead to lower overall rates as local authorities competed for investment: 'All the evidence shows that increased tax competition between jurisdictions will mean lower taxes - which will leave more money for businesses to spend on investing and growing' ${ }^{5}$ 
In many strongly devolved states, however, national governments place limits on the degree to which jurisdictions can compete through tax incentives in order to prevent wasteful forms of competition that benefit mobile firms rather than local taxpayers. These rules are replicated at the EU scale even if sometimes they are breached in practice. In the German case, for instance, strong structures of sub-national government, notably in the form of the Länder and strong city governments, exist alongside explicit and transparent mechanisms that transfer resources from economically stronger to economically weaker regions.

In federal states such as Brazil or the United States, where there are few if any limits on fiscally-based territorial competition, there is evidence that economic development strategies based on ever greater cuts to business taxes or generous financial incentives to mobile investors, supports a race to the bottom. In the US, several of the states with the most deregulated labour markets and lowest taxation rates are among the poorest, while the gap between the richest and poorest states in widening. Counter-intuitively, from the perspective of the ruling English orthodoxy, a recent analysis shows that high tax, heavily regulated Minnesota, has out-performed, low tax, minimally regulated Wisconsin, according to the main social and economic indicators. ${ }^{6}$

In England an attempt is underway to create a system of devolution that embeds it within a strong centrally imposed tax cutting agenda. Meanwhile, the devolution of business rates will work to the advantage of those areas best placed to attract new businesses allowing them to expand their tax base and fund local services and invest in infrastructure that, in absence of 
fiscal solidarity, are likely to lead to greater regional inequality. This outcome is strongly feared by some - if not all - local authority leaders in the north of England?

\section{Democratic renewal or post-democracy?}

The impact of devolution on democratic renewal is similarly contingent on the forms of decentralisation that are adopted. Central to the emerging English model is the role of the directly-elected Mayor. In the absence of convincing evidence about the impact of directlyelected Mayors on local economic growth and the improvement of local services, many of the claims made in the English debate rest on more or less persuasive anecdotes drawn principally from the US experience, and the limited experience in London. ${ }^{8} \mathrm{~A}$ frequent assertion in the debate about Mayors is that they have proved successful in the management of US cities. For instance, the economic resurgence of New York City is often attributed to the pro-business policies of 'strong mayors' such as Michael Bloomberg.

Rather less attention, however, is devoted to counterfactuals. We might look at the case of Detroit where 'strong mayors' have presided over a vicious circle of economic decline and municipal bankruptcy. In contrast to the claims of Grant Thornton/Localis, a high degree of local self-financing, far from ensuing resilience, was arguably a causal factor in the precipitous decline of Detroit. The Mayoral system is in crisis in Detroit. In 2013, the $65^{\text {th }}$ Mayor of Detroit, Kwame Kilpatrick, was sentenced to 28 years in prison after being convicted of a variety of corruption charges. The city of Detroit filed for bankruptcy in 2013 and the State of Michigan appointed an emergency manger to assume control the council. Strong Mayors can lead to 
hubris and over-reach and be the antithesis of models policymaking based on deliberation and increased accountability and scrutiny.

Mayors have managed both the rapid recent growth of New York City and the catastrophic decline of Detroit. Isolating the influence of Mayors amongst the many others factors at work in these cases is very difficult. One thing can be said with certainty is that the Mayors have not presided over an era of a democratic renewal. On the contrary the US mayoral system has been associated with declining levels of electoral participation in the big cities. At the time Robert F Wagner Jnr was elected as Mayor of New York City in 1953 voter turnout was over 90 per cent. By the time Bill de Blasio was elected $109^{\text {th }}$ mayor in 2013; voter turnout was less than 30 per cent. Similar rates of decline in voter turnout can be seen in cities such as Philadelphia, Los Angeles and Chicago. ${ }^{9}$ These declines in voter turnouts have occurred, moreover, in cities that are endowed with much more extensive local media than northern English cities. The rapid decline in the quality and quantity of local media in English cities makes the predictions of Grant Thornton/Localism, reported above, look highly optimistic.

A key feature of the US mayoral model concerns the way it facilitates close relationships between local political and business elites in ways which typically lack transparency and scrutiny and which underpin models of economic development that favour urban property interests. It is this aspect of the US model which seems to have had a particular influence in UK policy debates. For instance, at the 2015 Conservative Party conference in Manchester, George Osborne proposed that where elected mayors had been created they would have the power to add a (capped) infrastructure levy on business rates. There is considerable 
uncertainty about how both the devolution of business rates and the infrastructure levy would work in practice, but the government is clear that a levy can only be raised if a majority of 'business members' of the boards of Local Enterprise Partnerships agree. In effect, resources will only be allowed to be spent on infrastructure projects that are approved by a handful of 'business leaders'. It might fairly be asked why the interests of a small number of appointed business people should trump the mandate of an elected Mayor. It might even be argued that this development represents a partial return of the franchise property qualification which was abolished by the Representation of the People Act in 1918.

\section{Deal-making and devolution}

The new devolution arrangements are not the product of wide public debate in the areas to be affected by them, but instead are the outcomes of 'secret deals' (City Deals, 'Devolutions Deals', etc.) between political and business elites at the national and local scales, exemplified in the case of Manchester. ${ }^{10}$ In essence, these deals are assembled locally from a menu of policies approved by HM Treasury. It stretches the imagination to see this approach as leading to meaningful democratic renewal. On the contrary, the model of devolution currently on offer is one designed to advance a narrowly defined set of business interests with very little democratic scrutiny.

Underpinning the new policy is a theory of economic development that fosters inter-urban competition and economic concentration, tolerates and indeed even celebrates high levels of socio-economic inequality, is comfortable with some groups and places being losers and locks in enduring austerity, most especially in the places that have borne the brunt of public 
expenditure cuts to date. Innovation and entrepreneurialism in economic development is tolerated only within a highly restricted range of parameters. It is a form of devolution in which 'business' exercises a direct and indirect veto over the preferences of citizens. The emerging settlement is akin to the model of 'post-democracy', as elaborated by Colin Crouch, whereby formal mechanisms of accountability exist, but their practical role is increasingly limited and embodies the interest of a small elite. ${ }^{11}$

\section{Limits of devolution}

In an especially revealing set of remarks, one of the principal architects of the new orthodoxy went so far as to disavow the very mention of devolution as a description of the emerging policy regime. According to Lord Heseltine,

This is a partnership concept. Central governments are elected and they are entitled to have their manifestos implemented and it cannot be contemplated there is a sense of freedom at a local level which can actually frustrate the clear mandates upon which governments are elected....I am sympathetic to the word partnership rather than 'freedom' or 'devolution'. ${ }^{12}$

Far from creating Brandeis' 'laboratories of democracy', England is moving in the direction of an idiosyncratic, uneven and highly centralised form of multi-level government where devolved policymaking is approved only if it meets the criteria of central government (or precisely the Treasury), and often individual ministerial approval and selected business interests. It is likely to lead to a patchwork of governance arrangements that place many 
stresses on a shrinking central government as it seeks to manage a proliferation of local 'deals'.

Work by the OECD has identified the factors that are likely to limit the effectiveness of multilevel governance systems. Among these are asymmetries of information, lack of local technical capacity, insufficient funding, enduring policy fragmentation and a lack of transparency and accountability. The requirements for overcoming these coordination and capacity gaps includes, instruments for revealing and sharing information, significant investments in local capacity building, shared financing mechanisms and clear procedures for ensuring the integrity of governance systems and citizen involvement ${ }^{13}$. The ad-hoc, secretive, deal-based approach to devolution currently being introduced in England, together with the absence of mechanisms to manage inter-governmental relations, the eschewing of transparent and formal procedures of decision-making and the reliance on inter-personal relationships to manage the disbursement of significant amounts of public money, should be raising far more public concern than it has to date.

\section{Conclusion}

There are two central elements of the Conservative government's case for its particular approach to devolution. First, the rhetorical assertion that England is the most highly centralised country in the OECD and would benefit from increased democratic accountability at the sub-national level. Second, it is claimed that devolution will contribute to the rebalancing of regional economies through the creation of a (vaguely defined) 'Northern Powerhouse' or 'Midlands Engine'. However, the democratic advances involved in this 
approach are minimal at best and its underpinning economics are regressive. A strong argument could be made that, whatever their other weaknesses, there was more substance and resource attached to the Regional Development Agencies and the Northern Way project of the previous Labour government. To the extent that any significant policy proposals can be identified in relation to the 'Northern Powerhouse' - such as improving east-west transport links to increase the size of the Manchester labour market - these were filched from existing programmes and dressed up as new policy departures.

Given this lack of substance in the government's policy, what accounts for its relative marketing success (\#NorthernPowerhouse)? The answer probably lies in the fact that it has been personally adopted by the Chancellor, George Osborne, and deployed as a highly effective branding strategy and political tactic to divide and rule northern Labour controlled cities which are encouraged to compete with each other for speculative property deals that accelerate the development of their city centres, even if this model of economic change is contributing to rising levels of economic inequality and associated social tensions. The likely winners in this intra-Northern competition, unsurprisingly, are the greatest enthusiasts for this approach.

None of this is to deny the case for devolving power in England - that case is strong in principle. Nor is it to deny that selected aspects of the localist agenda in some contexts - for instance at the neighbourhood scale - may open spaces for citizens to assert their interest in the face of unresponsive bureaucracies. But the overall lines of tendency in the policy agenda suggest such developments will remain at the margins. There is more than one type of 
devolution. The impacts are of decentralisation are contingent upon its design. As the World Bank argues:

... [decentralisation programmes] can be successful or unsuccessful depending on how they are implemented ... Arguing about whether decentralization should happen is largely irrelevant; the way it is implemented will determine how successful it is ... decentralization is almost always politically motivated ... [and] ... devising a successful decentralization strategy is complex because decision makers do not always fully control the decentralization process. ${ }^{14}$

Devolution programmes can be designed to meet different objectives. In England, the government is creating a system of devolution that is embedded within a centrally imposed tax cutting agenda, concentrates power in closed political and businesses elites and facilitates inter-jurisdictional competition. It is possible to envisage an alternative model of devolution based on fiscal solidarity and a genuine attempt to extend democratic accountability. This is not on offer by any party in England for the time being. In the meantime, those civic forces interested in a different kind of devolution might focus on making the case for a more transparent, accountable and economically sustainable alternative that rests on firm foundations of democratic legitimacy. As major changes are made to local and regional governance in England they can hardly be said to reflect the 'settled will' of the English people. To paraphrase G.K. Chesterton, the people of England have not spoken yet. Indeed, they have yet to be asked their opinion and there are no plans to do so. 


\footnotetext{
${ }^{1}$ I would like to Peter O'Brien, Jane Wills, Arianna Giovannini and anonymous referees for comments on a draft. Views are mine. I would also like to acknowledge the award of the Sir Ernest Simon Visiting Manchester Professorship at Manchester Business School for 2015-2016 during which this paper was written.

${ }^{2}$ G. Thornton/Localis, Making devolution work, October 2015

(http://www.grantthornton.co.uk/globalassets/1.-member-firms/unitedkingdom/pdf/publication/2015/making-devolution-work.pdf)

${ }^{3}$ J. Tomaney, A. Pike, A. Rodríguez-Pose, V. Tselios and G. Torrisi, (2011) Decentralisation outcomes: a review of evidence and analysis of international data. Final Report to Department for Communities and Local Government. London: Department of Communities and Local Government (http://www.communities.gov.uk/documents/corporate/pdf/2113061.pdf).

${ }^{4} \mathrm{M}$. Burton, 'Beware Westminster bearing gifts, former mandarin tells councils', Transport Network, $13^{\text {th }}$ October 2015 (www.transport-network.co.uk/Beware-Westminster-bearing-gifts-former-mandarin-tellscouncils/12198)

${ }^{5}$ D. Chakravarty, 'Devolving business rates to local councils in England is great news for taxpayers', Tax Payers Alliance, $5^{\text {th }}$ October 2015.

(www.taxpayersalliance.com/devolving_business_rates_to_local_councils_in_england_is_great_news_for_tax payers)

${ }^{6}$ A. Markusen, The High Road Wins. How and why Minnesota is outpacing Wisconsin, The American Prospect, Spring 2015 (http:// http://prospect.org/article/high-road-wins)

${ }^{7} \mathrm{M}$ O'Hara, Osborne's business rate changes undermine his northern powerhouse, The Guardian, 23 March (http://www.theguardian.com/public-leaders-network/2016/mar/23/osbornes-business-rate-changesnorthern-powerhouse)

${ }^{8}$ B. Barber, If Mayors Ruled the World: Dysfunctional Nations, Rising Cities, New Haven, CT: Yale University Press, 2013.

${ }^{9}$ M. Macciag, 'Voter Turnout Plummeting in Local Elections, Governing, October 2014

(http://www.governing.com/topics/politics/gov-voter-turnout-municipal-elections.html

${ }^{10} \mathrm{~S}$. Jenkins, 'The secret negotiations to restore Manchester to greatness', The Guardian, 12 February

(http://www.theguardian.com/uk-news/2015/feb/12/secret-negotiations-restore-manchester-greatness); see also J. Tomaney and A. McCarthy, 'The Manchester Model', Town and Country Planning, 84(5), 2015, pp233236

${ }^{11}$ C. Crouch, Post-democracy, Cambridge, Polity, 2004.

${ }^{12}$ Quoted in D Paine, "Heseltine: fiscal freedoms unlikely for most councils", Local Government Chronicle, 1st July, 2015.

${ }^{13}$ C. Charbit, (2011), "Governance of Public Policies in Decentralised Contexts: The Multi-level Approach", OECD Regional Development Working Papers, 2011/04, OECD Publishing.

(http://dx.doi.org/10.1787/5kg883pkxkhc-en)

${ }^{14}$ World Bank, Partnerships for Prosperity, Washington DC: Work Bank, 2000, p65
} 